\title{
Towards Marketing the Nubian Tourism and Hotel Services
}

\author{
Salama Ammar Mohame ${ }^{1}$ \\ Momen Kamel AbouElezz ${ }^{2}$ \\ Tamer Ahmed Abdulaziz 3 \\ Mahmoud Ahmed Mohammed Saleh ${ }^{1}$ \\ ${ }^{1}$ The High Institute for Tourism and Hotels (EGOTH)-Luxor, ${ }^{2}$ Faculty of Tourism and Hotels-Minia \\ University, ${ }^{3}$ High Institute for Tourism and Hotels- 6 of October City
}

\begin{abstract}
The purpose of this study is to market the Nubian character and to highlight the interesting artistic aspects of the Nubian heritage and to show the world its beautiful appearance. Nubia is considered one of the most significant areas with tourism components. Such components have not been exploited efficiently, which affects negatively the local development of the region. A survey is conducted a group of tourists that viewed the Nubian characters to get acquainted with their views on the provided tourism services. The results indicate that there is an agreement which there was a high level of motivation of travelling to the Nubian society.in addition to the statements Advantages of the Nubian inheritance. Moreover, the results showed that the hotel services provided in Nubian society were characterized by high level of service, which the statement of the quality of food and decor have the highest level of services provided in Nubian. Finally, implications and recommendations are discussed based on the results.
\end{abstract}

Keywords: Tourism, Nubia, Development, Hotel Service, Egypt, Marketing.

\section{Introduction}

The environment is often regarded as the major pull factor of tourist movements, contributing to the desirability and attractiveness of a tourist destination, and it is an indispensable asset to the tourism industry (Lim \& McAleer, 2005). Thus, tourism (especially natural-based tourism) highly depends on environment (Shaheer et al., 2018).

Tourism marketing is the administrative and technical process through which the official tourist agencies or tourist establishments and hotels can identify the current and potential selected markets, and adopt a system of communication with these markets to affirm and influence the needs, wants and motivations of tourists at the local, regional and international levels, and also fits between the tourism product and these desires and motivations, and thus achieves its objectives (Kotler \& Armstrong, 2010).

World Tourism Organization (UNWTO, 2005) has defined tourism marketing as," a management philosophy which, in the light of tourist demand, makes it possible through research, forecasting and selection of tourism products/services from suppliers, on the line with organization's purpose and tourist satisfaction".

\section{Literature Review}

Travel and tourism are one of the largest economic sectors, creating jobs, drives exports, and increasing exports and fostering wealth around the globe. The sector comprised of a wide range of industries, aims to serve and assisting domestic, international, business and leisure visitors. Companies, large and small, in industries ranging from lodging and transportation to food \& beverage, retail and culture and sports \&entertainment, all aim to create products and services that bring people together, help communities and celebrate the wonders that our planet can offer (World Travel and Tourism Council, 2019).

Tourist and hotel services is defined as "a set of jobs and activities that provide tourists with comfort and facilities when purchasing and consuming tourist goods and services during their travel or stay in tourist facilities away from their original homelands" (Sahan, 1998). Because of its profound impact on destination preference, consumption level and loyalty, tourist satisfaction 
has been a long-standing and over-researched subject in tourism research, with diverse efforts devoted to investigate its development and precedents (e.g. Ahmed, 1991; Chen, et al., 2016, McDowall, 2011; Song, van der Veen, Li, and Chen, 2012; Xu and Zhang, 2016). Previous satisfaction-based studies in both marketing and tourism research have been driven by an expectancy-disconfirmation paradigm (EDP), which maintains that guest satisfaction is the produce of difference between expectation and service performance. As such, expectation affects satisfaction indirectly through disconfirmation with actual service performance, whether it is positive disconfirmation (performance exceeds expectation) or negative disconfirmation (performance exceeds expectation) (Oliver, 1980 and Weber, 1997).

Looking at the Nubian tradition that can be active in the service of the various tourist delegations that may be attracted to the experience of Nubians, they can also be used to achieve the tourism plans established in the region and work to find suitable and permanent employment opportunities and train them to work in tourism field, serving tourists and taking advantage of their primitive products, which are accepted by tourists, such as decorative tools made of local stones and materials, as well as some small environmental industries represented in handicrafts such as baskets, kilims, flooring, carpets and pottery etc. Many inhabitants also work in antiques selling and as tour guides. In addition, they work on sailboats and motorized boats to serve foreign and domestic tourism (Mahmoud, 2013).

\section{Tourism Market}

Research by the World Travel \& Tourism Council's (WTTC) showed that the industry accounted for $10.4 \%$ of global GDP and 319 million jobs, or 10\% of total employment in 2018, in its annual quantifying the global economic and employment impact of Travel \& Tourism in 185 countries and 25 regions. The overall consumption division is heavily weighted toward the leisure industry, which accounted for $78.5 \%$ of total business spending compared to $21.5 \%$, and the sector accounted for $6.5 \%$ of total global export and $27.2 \%$ of total global service exports. Domestic tourism, which accounted $71.2 \%$ of all tourism spending in 2018 and had the highest growth in developed countries, continues to support opportunities by spreading development and regional economic benefits and building national pride (WTTC, 2019).

Tourism has become one of the most central forms of economic relations between most countries. The importance of studying the tourism market and its parts emerged to find the most significant methods to develop tourism. The study of the tourism market is one of the most important studies carried out by Egypt because it plays an important role in identifying the nature of this market in terms of being a major, secondary or potential market, in addition to the possibility of understanding the characteristics of each market segment, in order to develop the optimal marketing strategy to face them (Al-Khudairi, 2002).

The tourism market in its simplest form represents all individuals and institutions seeking to satisfy the needs and desires of certain tourist places that offer a set of tourism products that are associated with a tourist site, supported by some factors, including transport, hotels, restaurants and others (Hudson, 2008).

Offered tourism services signify an effective human effort for tourists in all its forms, whether in the form of a variety of services in terms of food and beverages such as restaurants and cafes, or accommodation facilities such as hotels, hostels, apartments, camps or other facilities (McCabe, 2009).

\section{Tourism Services}

- The term 'tourist services' is defined as a set of works that provide tourists with comfort and various facilities when consuming services and tourist goods during the time of travel or their stay in tourist facilities away from their homelands. 
- Tourist services includes one of the following items:

- Natural Heritage: it exists in landscape and geography.

- Human heritage: demographic findings, life conditions, customs and traditions.

- Organizational, political, legal and administrative aspects of the country.

- Means of services of transport, accommodation, restaurants and others.

- Economic and financial activities.

- Most tourist sites provide inclusive tourism products and services such as cultural and recreational items, services related to influences, social services, religious services, etc., aiming to form a strategy for a tourism product (Davis, 2013).

\section{Types of Tourist Services}

Most researchers agreed to classify tourism services into two sections: the first is the basic services which are essential and fundamental for making tourism activity; the second is the complementary services which are those services that are either supplementary services that add additional value to customers or services that facilitate the basic service used to deliver the service or assist in the use of the basic service. Complementary services play a crucial role in distinguishing basic service from competing services (Al Dabbas, 2007 and Tawfik, 2008).

All of them focus on services that satisfy the needs and desires of the tourist or visitor when making trips, tours or religious visits, so tourism services can be classified as follows: (British Columbia Ministry of Jobs, Tourism and Skills Training, 2013).

- Accommodation and hospitality services: Today the accommodation is the main pillar in the field of travel and tourism, which are hotels of all kinds, villages, tourist cities, hostels and more.

- Transport services: Transport is the backbone of the tourism, travel and trade industry, and constitutes a large part of tourist spending as tourist trips include a comprehensive transport service (ground-sea-air) amid competition in terms of service level and prices.

- Food and beverage services: include everything that meets tourists' food and drink needs.

- Entertainment services: Excursions for recreation a well as sports, cultural, social services and others.

- Other complementary services include water, electricity, telephone, health services, maintenance, banking, laundry, security and tranquility, car parking, shaving, photography, sanitation and signs.

\section{Characteristics of Tourist Services}

Tourist services are characterized by numerous characteristics that distinguish them from other services. They are as follows:

1. The process of producing and consuming tourism services overlaps so that it is difficult to distinguish between them (Abu Qahf, 2006).

2. It is a service characterized by its intangible or moral nature, so that it cannot be seen or felt before purchasing it. (Laroche et al., 2001; Lovelock and Gummesson, 2004).

3. The inability of tourism services to be stored: the tourist on arrival has the sole aim of obtaining an intangible service (entertainment, accommodation, feeding, transportation), it is recognized that these services cannot be stored for later periods. Also, if the results of tourism services are not utilized, they cannot be stored. (Zeithaml et al., 1985; Bowen and Schneider, 1988; McDougall and Snetsinger, 1990; Wright, 1995; Vargo and Lusch, 2004).

4. Tourism services are jointly provided by tourism and non-tourism institutions (health, trade, telecommunications (Abu Qahf, 2006).

5. The human factor is the most influential factor on the provision of tourism service, so the tourism service depends on the element of personal marketing. For this reason, the provider 
of the tourism service must have special capabilities to enable him to deal well with the tourist or visitor and respond appropriately to all his questions and requirements, and how to convince him to make a positive decision to deal with the tourist service he provides (Abu Qahf, 2006).

6. Tourist services are not transferable: this means that most tourist services cannot be transported to where the tourist is located but requires him to be personally present to the desired location (Buhalis \& Darcy, 2011).

7. Difficulty in measuring tourist services: As the tourism organization believes that what it offers to the tourist is the best, the tourist may prefer to serve a particular tourist establishment more than other facilities because of criteria that do not take into account another tourist (Abu Qahf, 2006).

Services are generally intangible and impalpable, which means they are impossible to sense or touch, and cannot be separated from their provider because there is a strong connection between them. As a result, it is difficult to develop a particular pattern of services so that the service itself cannot be provided of the same quality (Moeller, 2010).

The services are also characterized by fluctuating demand, for they are characterized by change and diversity. In addition, tourism services have many characteristics that distinguish them from other services due to partly the nature of tourism itself, and the other part depends on the kind of the distinguished needs that are fulfilled through presenting various services. The most important characteristics are as follows: (Abu Qahf, 2006)

- Tourism requires kind and quality of services because it satisfies the needs and desires of individuals during their free time to achieve well-being and comfort.

- Speed in providing services to satisfy tourists during their time at the tourist site in order to enjoy their time and use all other tourist possibilities.

- The process of providing tourism services begins and ends at the time its production, which means that it is perishable.

- Most tourist services depend on the human element in their production and delivery process, for they are provided directly to tourists.

- The great variety of forms and media of tourism services because customers are heterogeneous in terms of nationality, age, social class, material ability, interests and experience in tourism.

- Services provided to tourists unite the efforts and actions of many individuals such as the efforts of tourism professionals and the efforts and actions of other companies and organizations such as transportation, communications, and others.

- Direct and continuous friction between staff and tourists results in in the judgement of the indigenous culture and literature of the indigenous region.

- Tourist services meet the basic needs of tourists such as sleeping, eating, drinking, etc. during their stay.

\section{Objectives of Tourism Marketing}

There are numerous objectives of tourism marketing, including:

1. Short-term objectives are those achieved by companies, tourism agencies, agencies and tourism organizations, which are to achieve a certain proportion of the tourist flow, whether in terms of the number of tourists, tourist nights or tourist revenues in a short period of time ranging from one year to Two years.

2. Long-term objectives: are the objectives covered by long-term tourism plans and are often set by the tourism companies and major travel agencies in the country, which are characterized by the large size of their tourism activity and the diversity of these material objectives to 
achieve a certain volume of tourist traffic (tourist flow) and the amount of a certain number of tourist revenues, as well as a certain number of tourist nights and the moral objectives of achieving great fame in the tourism field.

3. Various objectives: This type of objectives means that there is a diversity and variation of the marketing objectives sought by the various tourism establishments such as achieving satisfaction and meeting the different needs of tourists by improving the level of tourism services and upgrading them in addition to marketing objectives known as increased tourism income and tourism traffic as well as expansion and the opening of new tourist markets (ElHadded, 2009).

4. Common objectives: These are the marketing objectives that various tourism agencies, organizations and companies seek to achieve a good tourism reputation or provide highly advanced and developed tourism services... Etc. These objectives are shared by all tourist facilities.

5. Special objectives: This type of objective is linked to the achievement of certain objectives sought by a tourism establishment in particular, such as monopolizing a particular tourist market or providing excellent tourism services at moderate prices to other special objectives sought by the tourism establishment (Al Zuaabi, 2013).

Tourism marketing objectives can also be outlined in the following points (Al-Sarabi et al., 2011):

- Satisfying tourists: Marketing is considered to be a process of satisfying tourists and the main goal of applying the principles of marketing in the provision of tourism services is to satisfy consumers (Gronroos, 1984).

- Making the best use of available resources: Estimating consumer expectations makes it possible to manage resources and tourism supply in line with demand. This reduces the optimized exploitation of resources, so marketing based on a proper appreciation of the needs and expectations of tourists makes it easy to organize the business and activities of tourism institutions in proportion to this (Parasuraman et al., 1988).

- Making profits: On of the objectives of tourism marketing is to help the organization to make profits, without a doubt this is a long-term goal, while the economy of operation, the expansion of the market, and the giving of a new image of the tourism organization are all necessary to make profits(Chaudhuri, 2002).

- Clear Visibility: Among the goals of tourism marketing is to help the organization to raise its clear visibility and the principles of real tourism marketing are influential in creating or eliminating the impressions of tourists in the target markets.

- Superiority over competitors: This goal is significant for tourism marketing and today the competition is more intense and influential than before. Moreover, marketing practices facilitate the adoption of an appropriate strategy where the objectives of enterprises are accomplished with the help of marketing decisions and through that it is often the tourism organization tends to make its products the leading position making it difficult for competitors to enter or compete in the tourist markets (Kwun, 2010).

\section{Hotel activity}

The hotel is a complex and integrated service activity with relationships with several sectors, so the hotel management ensures that these activities are carried out in order to achieve its objectives. 
It is a service activity consisting of providing a variety of services to guests and other customers, but this activity requires that the hotel engage in administrative, commercial and other activities, so hotel management is distinct from other departments in other activities. It is an integrated and distinct activity consisting of a range of consistent functions (Parasuraman et al., 1988).

The hotel activity combines several sections as the following:

Sections have direct connection to guests such as front offices and restaurants. Sections that do not have direct contact with guests, but their service are necessary and important for departments that have direct contact with the departments such as accounts, purchases, kitchen and other hotel sections. The hotel activity also has a unique nature and characteristics; the hotel business has features such as: (Cooper et al, 2008)

- Innovation: An employee can innovate and develop hotel products and services.

- Promotion: means progressing in the career ladder and engaging in various administrative works.

- Achievement: Is to perform the work to the fullest and achieve the satisfaction of the guest.

- Supervision: The employee learns how to follow up and evaluate different works.

- Diversity: There is no routine work but a diversity of tasks within the confines of each job.

\section{Characteristics of Hotel Activity}

Through the services the hotel offers guests, the hotel activity has characteristics that distinguish it from other commercial, industrial, and other services. These characteristics are summed up as follows:

A. Seasonality of activity: as a result of the different degree and size of tourism activity from one time to another throughout the year, and related to the climatic and natural conditions of the state, and the tourist demand for hotel accommodation at specific periods and seasons, especially in remote areas, which has created some negative effects such as increased fixed and variable costs due to sometimes low rates of hotel activity (Guo et al., 2014).

B. Service activity: The origin of the hotel activity, regardless of the size of the hotel, is to perform services such as overnight, accommodation and subsistence, to provide meals, drinks and other service to entertain guests, book hotels for future trips...etc (Guo et al., 2016).

C. Hotel activity's reliance on the human element: hotel activity draws mainly on the use of the human element in achieving the general objectives, where the success of this activity depends on the efficiency, ability and excellence of the employees in the good treatment of the guest and the performance of the required work in a high spirit and activity with the availability of ingredients The personality of the human element as honesty is sincerity in work, honesty and other ingredients (Hwang and Wen, 2009).

D. Quick cash transactions: The hotel activity is distinguished from other activities, for it deals mostly with clients and customers in cash. These transactions are mainly cash transactions characterized by speed as the resident or guest deals with the hotel management for a specified period of stay to pay the duration of the stay and various other services provided before leaving the hotel.

\section{Marketing of Hotel Services}

Hotel marketing is defined as satisfying the needs and desires of hotel guests through hotel products and services and is presented in a coordinated manner with the needs and desires of guests (Kotler et al., 2009). 
Hotel marketing is also defined as a set of practices aim at satisfying the needs of different guests, through hotel products, through their value, evaluation, introduction, and facilitation of acquisition through mutual relationships (Matar, 2014).

Through the above definitions the concept of marketing in the field of hotel can be more illustrated through: (Hijazi, 2005).

- Marketing practices are activities aiming at satisfying the needs and desires of guests at the hotel.

- Hotel products are a combination of goods and services that serve the needs and desires of guests.

- The configuration process is a function based on design, preparation, and configuration to suit the needs and desires of guests.

- Appropriate distribution outlets play key roles in facilitating the acquisition of hotel products in the right place and time.

- The promotional mix plays a key role in introducing hotel products.

- Exchange is conducted through individuals who have competence, performance effectiveness, and properly aware of the hotel organization's guests.

\section{Marketing Mix of Hotel Services}

Hotel Marketing Mix is a detailed set of tools that are integrated to develop the hotel service that suits the needs and desires of guests to achieve their satisfaction as well as the marketing objectives of the hotel (Kotler and Philip, 1985; Kotler and Armstrong, 2005). Among the elements of the hotel marketing mix are the following:

Hotel Product: A combination of services and goods, it is a collection of benefits that satisfy the needs and desires of guests at the hotel establishment (Kotler and Fox, 1995; Lo, 2005). Therefore, the hotel establishment should choose the appropriate strategies regarding the nature of the services to be provided and the extent of their diversity, they are all a combination of goods and sources of satisfaction, such as the general atmosphere of the hotel and its ideas and expectations, as well as the image, and the mentality that the hotel paints in the minds of resident and prospective customers (Hwang, 2006; Tsai, 2008; Li and Hung, 2009). The hotel product can, therefore, generally be defined as the tangible and intangible elements offered by hotel organizations in the target market (tourist/guest markets in order to satisfy the needs, desires and tastes of these guests.

Hotel pricing: Hotel pricing is an activity through which the satisfaction values in the product offered at a specific time and place are translated into monetary values according to the in circulation in the community (Kotler and Fox, 1995; Lo, 2005).

The price of the service is not only determined by the monetary value it pays for the service, but there are other costs incurred by the guest in addition to the monetary value, and therefore the beneficiary decides whether the price of the service is appropriate for the benefits he/ she receives or not (Tsai, 2008).

The most important of these costs are (JHA, 2010):

1. The time the beneficiary spends receiving the service.

2. His financial effort in exchange for the service.

3. The psychological cost of purchasing the service (e.g. mental effort, feelings of inadequate service or fear caused by receiving certain services). 
4. Sensory and neurological costs: they are caused by some uncomfortable and nerve-racking elements during service (e.g. irritating sounds, bad smells, bitter taste, cold, excessive heat, uncomfortable seats, unattractive environment...).

5. Price is one of the most important aspects in the marketing of hotel services that requires creative and distinct practices on the part of the service producer, often the pricing policy tends to determine the pricing of rooms, food, beverage as well as entertainment and complementary services from shops and travel agencies and tourism.

\section{Nubia}

Nubia is known as "land of gold and diamonds"; its people are famous for their dark skin and kind hearts. Nubia is one of the most outstanding tourist areas in Egypt, which if we exploited it would be one of the most important elements of the national income of tourism, especially in the periods we live and the decline of Egypt on the map World tourism.

In that beautiful place and in a picturesque piece of Egypt in the south and on the banks of the Great Nile surplus with good and tender, giving life to all, located one of the most beautiful and important places in Egypt (Nubia) which took this name from the ancient Egyptian name Nebo, which means Gold.

For this reason, this area was called the land of gold. Moreover, this land was taken care of by all the rulers of Egypt since the era of the Pharaohs, and until now. It extends geographically about $500 \mathrm{~km}$ of which about $350 \mathrm{~km}$ inside Egypt and 150 in Sudan and what distinguishes that region from others is the great wealth in the natural resources that made the rulers of ancient Egypt send their caravans to discover gold and other minerals (Qabil, 2006).

Between every part of the Nubian villages, everywhere, between every house and walls, there is a paradise missing now where Nubians lived. That paradise is the strong link to the beautiful environment, the picturesque nature and the banks of the Nile, in that part of the land of Egypt, of which it is now part of it under the Nile and part of it has become a desert.

The Nubian character dominates the villages of Nubia, which has transformed it into the most famous tourist attractions that attract millions of tourists from around the world, to enjoy this atmosphere and visit these charming places, tourism has a very positive effect where there are many Nubian villages considered one of the most significant tourist sites to which tourists come from all over the world (Abdul Hafiz, 1982).

The Nubian heritage is characterized by rootedness, richness, and diversity. Moreover, it has its own peculiarity in the rest of the valley. It is natural that the Nubian folk heritage have various forms and expressions, including buildings, furniture, arts, ornaments, social customs, and traditions, etc. (Burkhardt, 1959).

\section{Tourism Sites of Nubia}

West Suhail Village

It is one of the Nubian communities in the city of Aswan and located on a sandy foot west of the Nile, the village was established about 100 years ago, when the old Aswan reservoir was built, and the most important feature of the village is the houses that have a Nubian character in their picturesque colors, as well as the raising of crocodiles inside the houses of the inhabitants, which is an important tourist aspect (Abdul Rahim, 1997).

The tourist can buy handmade products and wandering in the village riding camels and using the Nubian henna design on the body. Moreover, feeding and taming the Nile crocodiles that are reared in homes, and there is also Nubian food, especially the sun bread, which is served with cheese and black honey for foreigners as well as the distinctive wicker selections, beads, collars and traditional Nubian clothing such as gorgab, which is a light black jalabiya of hollow fabric with many fragments, and wear them over colored jalabiya (Kandoul, 2018). The village also has 
places to host tourists; the number of houses reached 50 houses with the establishment of a tourist marina on the Nile along 60 meters to receive the arrivals.

\section{Hisa Island}

Hisa Island is one of the oldest islands of Nubia and is named after the Pharaonic king 'Hess', whose inhabitants still live a primitive life, and what distinguishes it from other places is the dance parties and folk singing that attracts tourists from everywhere, as well as Nubian food and drink.

\section{Nubia Museum}

A museum created by UNESCO in Egypt to display monuments of ancient Nubian civilization, as well as information on the history of Nubia from prehistoric times to the present, with a review of the most important Nubian customs and traditions, and the ancient Nubian language. The museum permanently displays about 1,500 artifacts in the museum, arranged in a historical sequence that represents the physical culture of the shift from prehistoric times to the present day.

\section{Agilica Island}

It is one of the most important islands of Nubia due to its embrace of the temple and monuments of Philae, which was flooded by the Nile waters, it is mentioned that the monuments of the stomach of Philae have been dismantled and installed again 500 miles from the island, and are characterized by the $\mathrm{c}$

onstant display of sound and light in all different languages.

Nubia is one of the few tourist sites that has survived Egypt's current security warnings, and even has its charming location overlooking the banks of the legendary Nile, which provides visitors with more relaxation. There are prominent and significant tourism attractions in Nubia, including the Temple of Abu Simbel, the Temple of Philae, the High Dam and other landmarks that are signs of ancient Egyptian civilization and modern times.

Since Nubia is known with henna among the governorates of Egypt, drawing henna for tourists is a key requirement due to its attractiveness that reflect the Aswan culture in natural colours that do not harm the skin. Tourists ask for the drawing of the tattoo, which often expresses Paranoiac drawings and the life key. Nubia is also characterized by Nubian folk dance, which is usually a group dance involving men and women of all ages, and a number of these dances associated with the seasons of agriculture and harvest (Arajid).

Table 1: A Statement of Hotel Capacity in Aswan Governorate

\begin{tabular}{|l|l|l|l|l|l|}
\hline N. & Place of Residence & Tourist Class & Rooms Number & Beds Number & Sector Owner \\
\hline 1. & Movenpick Aswan & 5 Stars & 234 & 468 & Public Sector \\
\hline 2. & Aswan Village & 5 Stars & 288 & 576 & Investment Sector \\
\hline 3. & New Cataract & 5 Stars & 62 & 124 & public Sector \\
\hline 4. & Old Cataract & 5 Stars & 76 & 152 & public Sector \\
\hline 5. & Isis Island & 5 Stars & 447 & 894 & Private Sector \\
\hline 6. & Basma & 4 Stars & 210 & 420 & Private Sector \\
\hline 7. & City Abu Simbel & 4 Stars & 138 & 276 & Private Sector \\
\hline 8. & Nefertari Abu Simble & 4 Stars & 123 & 246 & Investment Sector \\
\hline 9. & Isis Chalets & 3 Stars & 100 & 200 & Private Sector \\
\hline 10. & Cleopatra & 3 Stars & 130 & 260 & Private Sector \\
\hline 11. & Welcome & 3 Stars & 78 & 156 & Private Sector \\
\hline 12. & Sarah & 2 Stars & 60 & 120 & Private Sector \\
\hline 13. & Applicators Hotel & 2 stars & 11 & 22 & Investment Sector \\
\hline 14. & The Prince & 2 stars & 36 & 72 & Private sector \\
\hline
\end{tabular}


International Journal of Heritage, Tourism and Hospitality Vol. (14), No. (1), June, 2020

\begin{tabular}{|l|l|l|l|l|l|}
\hline N. & Place of Residence & Tourist Class & Rooms Number & Beds Number & Sector Owner \\
\hline 15. & Nobaleh Ramsis & 1Star & 32 & 64 & Private Sector \\
\hline 16. & Tiba & 1 Star & 45 & 90 & Private Sector \\
\hline 17. & Oscar traditional & 1Star & 32 & 64 & Private Sector \\
\hline 18. & $\begin{array}{l}\text { Nubian } \\
\text { House Eskaleh }\end{array}$ & 5 & 10 & Private Sector \\
\hline 19. & Sunset & Under evaluation & 64 & 128 & Private Sector \\
\hline 20. & Helnan & Under evaluation & 195 & 390 & Investment Sector \\
\hline 21. & Kabara & Under Evaluation & 6 & 12 & Private Sector \\
\hline 22. & Anakato & Under evaluation & 5 & 10 & Private Sector \\
\hline
\end{tabular}

Source: General Administration of Information and Decision Support Centre (Statistics Department - Statistical Directory), Aswan Governorate (2019).

Table 1 shows the hotel capacity in Aswan Governorate where the total number of tourist hotels in the province according to different levels are 22 hotels these hotels contain 2393 rooms, with a capacity of 4786 beds. The aforementioned tourist hotels are divided by their levels to:

- Classified tourist hotels: that numbered 18 hotels which represents $81.8 \%$ of the total number of hotels in Aswan Governorate, and has a residential capacity of about 1993 rooms representing $86.5 \%$ of the total number of rooms in the province hotels, which contains 4246 beds, accounting for $87.22 \%$ of the total number of beds in hotel.

- Unclassified tourist hotels: 4 hotels represent 18.2\% of the total number of hotels, containing 270 rooms, accounting for about $13.5 \%$ of the total number of rooms, and include 540 beds representing $12.78 \%$ of the total number of beds.

Table 2: Tourist Hotels in Abu Simbel

\begin{tabular}{|c|c|c|c|c|}
\hline No & Place of residence & Class & Rooms Number & Beds Number \\
\hline 1. & Nefertari Hotel & 4 Stars & 120 & 240 \\
\hline 2. & City Abu Simbel Hotel & 4 Stars & 142 & 284 \\
\hline 3. & Nobaleh Hotel & 1 Star & 32 & 64 \\
\hline 4. & Applicators Hotel & 2 Stars & 11 & 21 \\
\hline 5. & Hotel Escalade & 1 Star & 5 & 10 \\
\hline \multicolumn{5}{|c|}{ Floating Hotels in Abu Simbel Tourist City } \\
\hline 6. & Prince Abbas & & & 93 \\
\hline 7. & Nubian Sea & & & 146 \\
\hline 8. & Omar Khayyam & & & 150 \\
\hline
\end{tabular}

Source: General Administration of Information and Decision Support Center (Statistics Department - Statistical Directory), Aswan Governorate (2019)

Table 3: Nubian Hotels in West Sohail

\begin{tabular}{|l|l|l|l|l|}
\hline \multicolumn{1}{|c|}{ No } & \multicolumn{1}{|c|}{ Place of residence } & Class & Rooms Number & Beds Number \\
\hline 1. & Anakato (1) & Unclassified & & \\
\hline 2. & Anakato (2) & Unclassified & & \\
\hline 3. & Hadouta Masreya & Unclassified & & \\
\hline 4. & Ashry Narty & Unclassified & & \\
\hline 5. & Nubian House & Unclassified & & \\
\hline 6. & Sara Hotel & Unclassified & & \\
\hline 7. & Kato Dool & Unclassified & & \\
\hline 8. & Ekadolli & Unclassified & & \\
\hline
\end{tabular}




\section{Nubian Cuisine}

Nubian cuisine is characterized by distinctive cuisines that are very different from other kitchens; the Nubian loves dry mallow or "powder" and prefers spicy foods in a great way, as well as an interest in the meat they use fresh and dry.

Nubian food is associated with cosmic phenomena, as the Nubians used to call a star that appears after Morocco and disappears after the time of the evening prayer "guest star" and its disappearance is a sign to the guests that the existing will be served and it is difficult for the host to prepare food for him.

With the appearance of the "three stars" gives a signal to the entry of the time of suhoor in the month of Ramadan, where it appears at about 1 a.m., while the "star of dawn" is a sign of the time of constipation.

The Nubians used to eat what was suitable for the morning and other foods that fit the evening. They also used to eat certain types of food "as a treatment" for certain diseases such as drinking drenched henna, eating the fruits of the acacia tree, treating wounds with castor oil, treating headaches with certain types of "Nile silt", eating salami, and for the treatment of kidney diseases and plants such as "camel's hay". Furthermore, they also use "Wormwood" and "thermos" to treat Diabetes and the use of the fenugreek and its seeds and it leaves sometimes.

Nubian cuisine is also one of the distinctive cuisines, and it is far from Egyptian cuisine and it is most important food is Nubian Jakud and mallow blended with green and parsley, but Nubian cuisine is rich in its variety of different varieties close to Sudanese cuisine and not Egyptian.

The most important dishes of Nubian cuisine are:

Al Jakud

It is made through dry okra, where Nubians are keen to dry okra in the sun, then a packet of coriander, dill and spinach, the vegetables are cooked in a bowl using 3 cups of water and chicken stock, the okra is gradually added to the mixture and chopped and fried garlic is added at the end of the preparation.

Al Jakrid: is prepared through spinach and a packet of dill and coriander. Ingredients are cooked in a vase with chicken soup or meat, add the garlic and leave on the fire until boiled and then rub the mixture.

Al Kashid: consists of cubes of meat and is cooked in ghee on low heat and adds the black pepper, and after the meat is cooked the salt is added and then served.

Al Kirmadid: It consists of flour and a floured fenugreek and oil. Fenugreek is cooked with oil, flour water, and salt. The mixture is cooked by an electric mixer and made in a "crumb" shape after the Nubian dukka is added.

Dokka Bread: prepared with the simplest ingredients of flour, water and half a teaspoon of salt, the ingredients are mixed and placed in a tray in a circle and cooked on both sides and prepared in less than 3 minutes.

Okra: is served in this dish with special taste, Okra is cooked in a bowl of chicken or other soup, and when fully cooked it is chopped to become liquid such as mallow, and then put a little garlic fried with ghee and eat with Dokka Bread.

\section{Research Problem}

Nubia is one of the most significant areas that have tourist attractions. These Tourist attractions are not optimized, which negatively affects local development in the region. Since trips to Aswan, whether groups or foreign individuals and citizens come to Aswan are limited in their tourist tour to the Nile or temples and archaeological areas, without visiting the Nubian villages 
or Lake Nasser or the desert, and this is due to the lack of interest in these areas by tour operators or supervisors.

Although Nubia is one of the most significant areas that have tourist attractions, these Tourist attractions are not developed in a sufficient way, thereby affecting local development in the region negatively. Moreover, Nubia suffers from the neglect of tour operators and not being included in their tourism programs, which led to a lack of interest in both of marketing the Nubian character and highlighting the artistic aspects of the Nubian heritage

\section{Research Objectives}

This research aims at achieving the following objectives:

- Highlighting the Nubian character and its role in attracting tourists.

- Spotting on the significance and role of marketing in tourism activity.

- Evaluating hotel services in that area

\section{Research design}

Questionnaire is considered one of major methods used to collect data (Bryman and Bell, 2007). Researchers used questionnaire to obtain information about the motivations that led to tending to travel to the Nubian society, data resources on the Nubian society, advantages of the Nubian inheritance, and desirable/preferable services in the journey to Nubian society and evaluation of hotel services provided. There are two important aspects for designing a questionnaire as indicated by Siniscalco and Auriat (2005): [1] the structure of the question and [2] the decisions on the types of response formats for each question. In terms of questionnaire structure, (Bryman and Bell, 2007) stated that questions can be classified into two main structures which are: [1] close-ended questions and [2] open-ended questions. Both types of questions were used in this study in order to get more information and also to achieve the aim and objectives of the research. For this study a self-administrated questionnaire was designed. The questionnaire was comprised of six sections. All items from the second to fifth sections were measured using a 5-point Likerttype scale (1: strongly disagree to 5: strongly agree) for the most of questions. The questionnaire included 41 questions providing information about the marketing hospitality and tourism services, which has the Nubian Aspects". The first part consisted of 4 questions related to the demographic data. The second part consisted of 5 statements related to the motivations that led to tending to travel to the Nubian society. The third part consisted of 4 statements which related to data resources on the Nubian society. The fourth part consisted of 10 statements which related to the advantages of the Nubian inheritance. The fifth part consisted of 3 statements which related to the Desirable / preferable services in the journey to Nubian society. The last part of the questionnaire consisted of 15 statements which related to the evaluation of hotel services provided. All items from the first to sixth part were measured using a 5-point Likert-type scale (1: strongly disagree to 5: strongly agree) for the following: "Please indicate your level of agreement with the following statement".

It is important to mention that the study community is consisting of a random sample of 150 tourists who were present in tourist and hotel establishments in the Nubian community in Aswan Governorate during the period from December 2019 to January 2020. At the end, the research offers recommendations based on the gathered data.

\section{Hypotheses of the study}

H1: Advantage of the Nubian inheritance affects motivation of travelling to the Nubian society. H2: Data resources on the Nubian society affect motivation of travelling to the Nubian society. H3: Level of hotel services provided affect motivation of travelling to the Nubian society. 
H4: There is a significant difference in motivation of travelling to the Nubian society according to age.

\section{Reliability}

Table 4: Cronbach's Alpha

\begin{tabular}{|l|l|l|}
\hline \multicolumn{1}{|c|}{ Variables } & Cronbach's Alpha & No. of items \\
\hline Motivations that led to tending to travel to the Nubian society & .779 & 5 \\
\hline Data resources on the Nubian society & .739 & 4 \\
\hline Advantages of the Nubian inheritance & .768 & 10 \\
\hline Desirable/preferable services in the journey to Nubian society & .745 & 3 \\
\hline Evaluation of hotel services provided & .719 & 15 \\
\hline
\end{tabular}

As depicted in table 4, the Cronbach's Alpha reliability was computed for five parties and the tests showed that the reliability coefficients for all the parties were above .71 which indicates that the instrument is reliable for being used.

\section{Descriptive analysis}

Table 5: Basic data of respondents

\begin{tabular}{|l|c|c|}
\hline \multicolumn{2}{|c|}{ Frequencies } & Percentage \\
\hline Gender & 49 & 46.7 \\
\hline Male & 56 & 53.3 \\
\hline Female & 105 & 100 \\
\hline Total & \multicolumn{2}{|c|}{} \\
\hline Age & 30 & 28.6 \\
\hline $15-24$ & 21 & 20 \\
\hline $25-35$ & 25 & 23.8 \\
\hline $36-44$ & 29 & 27.6 \\
\hline 45 and above & 105 & 100 \\
\hline Total & \multicolumn{3}{|c|}{} \\
\hline Marital status & 35 & 33.3 \\
\hline Single & 63 & 60 \\
\hline Married & 7 & 6.7 \\
\hline Other & 105 & 100 \\
\hline Total & \multicolumn{3}{|c|}{} \\
\hline
\end{tabular}

Table 5 indicates that $53.3 \%$ of the respondents were female, and $46.7 \%$ were male. Regarding the age of respondents, $28.6 \%$ of the respondents were between 15-24 years, followed by who were between more than 45 years by $27.6 \%$, then who were between $36-44$ years by $23.8 \%$, and finally, who were between $25-35$ years by $20 \%$. As for the marital status of the respondents, $60 \%$ of the respondents were married, $33.3 \%$ were single, and $6.7 \%$ were neither single nor married. Respondents' jobs varied between accountant (1), captain(1), civil engineer (2), cleaner (1),company manger (1), doctor (9), engineer (1), as well as farmer (2), general manager (1), house women (5), manager (1), professor (1), retired (5), students (21), teacher (17), travel agent (1), and finally who were without jobs (35).

\section{Motivations that led to tending to travel to the Nubian society}

$1=$ strongly disagree $; 2=$ disagree $; 3=$ neutral $; 4=$ agree $; 5=$ strongly agree

Table 6: Motivations of travelling to the Nubian society

\begin{tabular}{|l|l|l|l|l|l|l|l|l|}
\hline Items & & $\mathbf{1}$ & $\mathbf{2}$ & $\mathbf{3}$ & $\mathbf{4}$ & $\mathbf{5}$ & Mean & SD \\
\hline \multirow{2}{*}{ Monumental sites seeing } & Freq. & - & - & 7 & 80 & 18 & 4.10 & .47 \\
\cline { 2 - 10 } & $\%$ & - & - & 6.7 & 76.2 & 17.1 & & \\
\cline { 1 - 9 } Enjoying weather and nature beauty & Freq. & - & - & 11 & 78 & 16 & \multirow{2}{*}{4.05} & .50 \\
\cline { 2 - 8 } & $\%$ & - & - & 10.5 & 74.3 & 15.2 & & \\
\hline
\end{tabular}




\begin{tabular}{|c|c|c|c|c|c|c|c|c|}
\hline Items & & 1 & 2 & 3 & 4 & 5 & Mean & SD \\
\hline \multirow[t]{2}{*}{ Recognizing Nubian inheritance } & Freq. & - & 1 & 11 & 64 & 29 & \multirow[t]{2}{*}{4.15} & \multirow[t]{2}{*}{.63} \\
\hline & $\%$ & - & 1 & 10.5 & 61 & 27.5 & & \\
\hline \multirow[t]{2}{*}{ Residence Nubian hotels } & Freq. & - & - & 6 & 35 & 64 & \multirow[t]{2}{*}{4.55} & \multirow[t]{2}{*}{.60} \\
\hline & $\%$ & - & - & 5.7 & 33.3 & 61 & & \\
\hline \multirow[t]{2}{*}{ Eating Nubian meals } & Freq. & - & 2 & 7 & 31 & 65 & \multirow[t]{2}{*}{4.54} & \multirow[t]{2}{*}{.66} \\
\hline & $\%$ & - & 1.9 & 6.7 & 29.5 & 61.9 & & \\
\hline Total & & & & & & & 4.28 & .33 \\
\hline
\end{tabular}

Table 6 depicts that there was a high level of motivation of travelling to the Nubian society (the mean= $4.28 \& \mathrm{SD}=.33$ ). The table also clarified that there were many motivators for travelling to the Nubian society. Residence Nubian hotels was the highest motivator for travelling to the Nubian society by mean 4.55 and SD .60, followed by eating Nubian meals by mean 4.54 and SD .66, then recognizing Nubian inheritance by mean 4.15 and SD .63, then monumental sites seeing by mean 4.10 and SD .47, and finally, enjoying weather and nature beauty by mean 4.05 and SD .50.

Table 7: Resources suitable for gathering data about the Nubian society

\begin{tabular}{|c|c|c|c|c|c|c|c|c|}
\hline Items & & 1 & 2 & 3 & 4 & 5 & Mean & SD \\
\hline \multirow[t]{2}{*}{ Internet } & Freq. & 4 & 33 & 15 & 26 & 27 & \multirow[t]{2}{*}{3.36} & \multirow[t]{2}{*}{1.28} \\
\hline & $\%$ & 3.8 & 31.4 & 14.3 & 24.8 & 25.7 & & \\
\hline \multirow[t]{2}{*}{ Television channels } & Freq. & 2 & 4 & 36 & 35 & 28 & \multirow[t]{2}{*}{3.80} & \multirow[t]{2}{*}{.92} \\
\hline & $\%$ & 1.9 & 3.8 & 34.3 & 33.3 & 26.7 & & \\
\hline \multirow[t]{2}{*}{ Tourist agent } & Freq. & - & 2 & 27 & 43 & 33 & \multirow[t]{2}{*}{4.02} & \multirow[t]{2}{*}{.80} \\
\hline & $\%$ & - & 1.9 & 25.7 & 41 & 31.4 & & \\
\hline \multirow[t]{2}{*}{ Friends \& relatives } & Freq. & - & 2 & 25 & 52 & 26 & \multirow[t]{2}{*}{3.99} & \multirow[t]{2}{*}{.72} \\
\hline & $\%$ & - & 1.9 & 23.8 & 49.5 & 24.8 & & \\
\hline
\end{tabular}

Table 7 shows that there were many sources of data about the Nubian society. Results revealed that tourist agent was the most important source of data by mean 4.02 , followed by friends \& relatives by mean 3.99 , then television channels by mean 3.80 , and finally, internet by mean 3.36.

\section{Advantages of the Nubian inheritance}

Table 8: Advantages of the Nubian inheritance

\begin{tabular}{|c|c|c|c|c|c|c|c|c|}
\hline Items & & 1 & 2 & 3 & 4 & 5 & Mean & SD \\
\hline \multirow[t]{2}{*}{ Nubian arts } & Freq. & - & - & 9 & 31 & 65 & \multirow[t]{2}{*}{4.53} & \multirow[t]{2}{*}{.65} \\
\hline & $\%$ & - & - & 8.6 & 29.5 & 61.9 & & \\
\hline \multirow[t]{2}{*}{ Participation at Nubian Nights } & Freq. & - & - & 11 & 76 & 18 & \multirow[t]{2}{*}{4.08} & \multirow[t]{2}{*}{.51} \\
\hline & $\%$ & - & - & 10.5 & 72.4 & 17.1 & & \\
\hline \multirow[t]{2}{*}{ Nubian foods \& beverages } & Freq. & - & 2 & 4 & 70 & 29 & \multirow[t]{2}{*}{4.21} & \multirow[t]{2}{*}{.56} \\
\hline & $\%$ & - & 1.9 & 3.8 & 66.7 & 27.6 & & \\
\hline \multirow{2}{*}{ Nubian folktales } & Freq. & 1 & 2 & 12 & 51 & 39 & \multirow[t]{2}{*}{4.22} & \multirow[t]{2}{*}{.75} \\
\hline & $\%$ & 1 & 1.9 & 11.4 & 48.6 & 37.1 & & \\
\hline \multirow[t]{2}{*}{ Customs \& traditions } & Freq. & - & - & 14 & 23 & 68 & \multirow[t]{2}{*}{4.51} & \multirow[t]{2}{*}{.72} \\
\hline & $\%$ & - & - & 13.3 & 21.9 & 64.8 & & \\
\hline \multirow[t]{2}{*}{ Nubian hand made } & Freq. & - & - & 3 & 52 & 50 & \multirow[t]{2}{*}{4.45} & \multirow[t]{2}{*}{.55} \\
\hline & $\%$ & - & - & 2.9 & 49.5 & 47.6 & & \\
\hline \multirow[t]{2}{*}{ Nubian henna } & Freq. & - & 1 & 2 & 18 & 84 & \multirow[t]{2}{*}{4.76} & \multirow[t]{2}{*}{.52} \\
\hline & $\%$ & - & 1 & 1.9 & 17.1 & 80 & & \\
\hline \multirow[t]{2}{*}{ Nubian dialect \& accent } & Freq. & 1 & 4 & 9 & 81 & 10 & \multirow[t]{2}{*}{3.90} & \multirow[t]{2}{*}{.64} \\
\hline & $\%$ & 1 & 3.8 & 8.6 & 77.1 & 9.5 & & \\
\hline Nubian hotels & Freq. & - & - & 8 & 50 & 47 & 4.37 & .62 \\
\hline
\end{tabular}




\begin{tabular}{|l|l|l|l|l|l|l|l|l|}
\hline Items & & $\mathbf{1}$ & $\mathbf{2}$ & $\mathbf{3}$ & $\mathbf{4}$ & $\mathbf{5}$ & Mean & SD \\
\hline \multirow{2}{*}{ Nubian folklore } & $\%$ & - & - & 7.6 & 47.6 & 44.8 & & \\
\cline { 1 - 10 } & Freq. & - & 1 & 10 & 35 & 59 & 4.45 & .70 \\
\cline { 2 - 9 } & $\%$ & - & 1 & 9.5 & 33.3 & 56.2 & & \\
\hline
\end{tabular}

Table 8 clarifies that the Nubian inheritance has many advantages. Results indicated that Nubian henna was the most important advantage of the Nubian inheritance by mean 4.76 , followed by Nubian arts by mean 4.53 , then customs and traditions by mean 4.51 , then Nubian handmade and Nubian folklore by the same mean 4.45 , then Nubian hotels by mean 4.37 , followed by Nubian folktales by mean 4.22 , then Nubian foods and beverages by mean 4.21 , then participation at Nubian Nights by mean 4.08, and finally, Nubian dialect and accent by mean 3.90. Some of respondents added that Nubian hospitality, music, singer and widening are from advantages of the Nubian inheritance.

\section{Desirable / preferable services in the journey to Nubian society}

Table 9: Desirable / preferable Means of Transportation in the journey to Nubian society

\begin{tabular}{|l|l|l|l|l|l|l|l|l|}
\hline Items & & $\mathbf{1}$ & $\mathbf{2}$ & $\mathbf{3}$ & $\mathbf{4}$ & $\mathbf{5}$ & Mean & SD \\
\hline \multirow{2}{*}{ Plan/flight } & Freq. & 2 & 41 & 14 & 45 & 3 & 3.06 & 1.00 \\
\cline { 2 - 10 } & $\%$ & 1.9 & 39 & 13.3 & 42.9 & 2.9 & & \\
\hline \multirow{2}{*}{ Railway } & Freq. & - & 7 & 28 & 20 & 50 & 4.08 & \multirow{2}{*}{1.00} \\
\cline { 2 - 9 } & $\%$ & - & 6.7 & 26.7 & 19 & 47.6 & & \\
\hline \multirow{2}{*}{ Runway (Bus - Car) } & Freq. & 1 & 2 & 41 & 53 & 8 & \multirow{2}{*}{3.63} & .68 \\
\cline { 2 - 8 } & $\%$ & 1 & 1.9 & 39 & 50.5 & 7.6 & & \\
\hline
\end{tabular}

Table 9 reveals that railway was the most desirable means of transport in the journey to Nubian society by mean 4.08 , followed by runway (bus or car) by mean 3.63. Plan or flight was the lowest desirable service in the journey to Nubian society by mean 3.06.

\section{Evaluation of hospitality and tourism services provided}

Table 10: Evaluation of hotel services provided

\begin{tabular}{|c|c|c|c|c|c|c|c|c|}
\hline Items & & 1 & 2 & 3 & 4 & 5 & Mean & SD \\
\hline \multirow[t]{2}{*}{ Menu variety } & Freq. & - & - & 2 & 86 & 17 & \multirow[t]{2}{*}{4.15} & \multirow[t]{2}{*}{.38} \\
\hline & $\%$ & - & - & 1.9 & 81.9 & 16.2 & & \\
\hline \multirow[t]{2}{*}{ Value for price paid } & Freq. & - & 2 & 8 & 64 & 31 & \multirow[t]{2}{*}{4.18} & \multirow[t]{2}{*}{.64} \\
\hline & $\%$ & - & 1.9 & 7.6 & 61 & 29.5 & & \\
\hline \multirow{2}{*}{ Promptness of service } & Freq. & - & - & 10 & 87 & 8 & \multirow[t]{2}{*}{3.98} & \multirow[t]{2}{*}{.41} \\
\hline & $\%$ & - & - & 9.5 & 82.9 & 7.6 & & \\
\hline \multirow{2}{*}{ Quality of service } & Freq. & - & - & 7 & 63 & 35 & \multirow[t]{2}{*}{4.26} & \multirow[t]{2}{*}{.57} \\
\hline & $\%$ & - & - & 6.7 & 60 & 33.3 & & \\
\hline \multirow[t]{2}{*}{ Quality of food } & Freq. & - & - & 3 & 40 & 62 & \multirow[t]{2}{*}{4.56} & \multirow[t]{2}{*}{.55} \\
\hline & $\%$ & - & - & 2.9 & 38.1 & 59 & & \\
\hline \multirow[t]{2}{*}{ Quality of beverage } & Freq. & - & - & 11 & 48 & 46 & \multirow[t]{2}{*}{4.33} & \multirow[t]{2}{*}{.66} \\
\hline & $\%$ & - & - & 10.5 & 45.7 & 43.8 & & \\
\hline \multirow{2}{*}{$\begin{array}{l}\text { Overall, how would you rate staff hospitality? } \\
\text { (friendliness, courtesy, responsiveness) }\end{array}$} & Freq. & - & 1 & 10 & 48 & 46 & \multirow[t]{2}{*}{4.31} & \multirow[t]{2}{*}{.68} \\
\hline & $\%$ & - & 1 & 9.5 & 45.7 & 43.8 & & \\
\hline \multirow[t]{2}{*}{ Overall, how would your public areas? } & Freq. & 1 & - & 4 & 69 & 31 & \multirow[t]{2}{*}{4.22} & \multirow[t]{2}{*}{.60} \\
\hline & $\%$ & 1 & - & 3.8 & 65.7 & 29.5 & & \\
\hline \multirow{2}{*}{$\begin{array}{l}\text { Overall, how would you rate ability to provide a } \\
\text { relaxing atmosphere? }\end{array}$} & Freq. & 2 & - & 9 & 69 & 25 & \multirow[t]{2}{*}{4.10} & \multirow[t]{2}{*}{.70} \\
\hline & $\%$ & 1.9 & - & 8.6 & 65.7 & 23.8 & & \\
\hline \multirow[t]{2}{*}{ Decor } & Freq. & - & - & 9 & 29 & 67 & \multirow[t]{2}{*}{4.56} & \multirow[t]{2}{*}{.64} \\
\hline & $\%$ & - & - & 8.6 & 27.6 & 63.8 & & \\
\hline \multirow[t]{2}{*}{ Cleanliness } & Freq. & - & 1 & 12 & 44 & 48 & \multirow[t]{2}{*}{4.33} & \multirow[t]{2}{*}{.71} \\
\hline & $\%$ & - & 1 & 11.4 & 41.9 & 45.7 & & \\
\hline
\end{tabular}




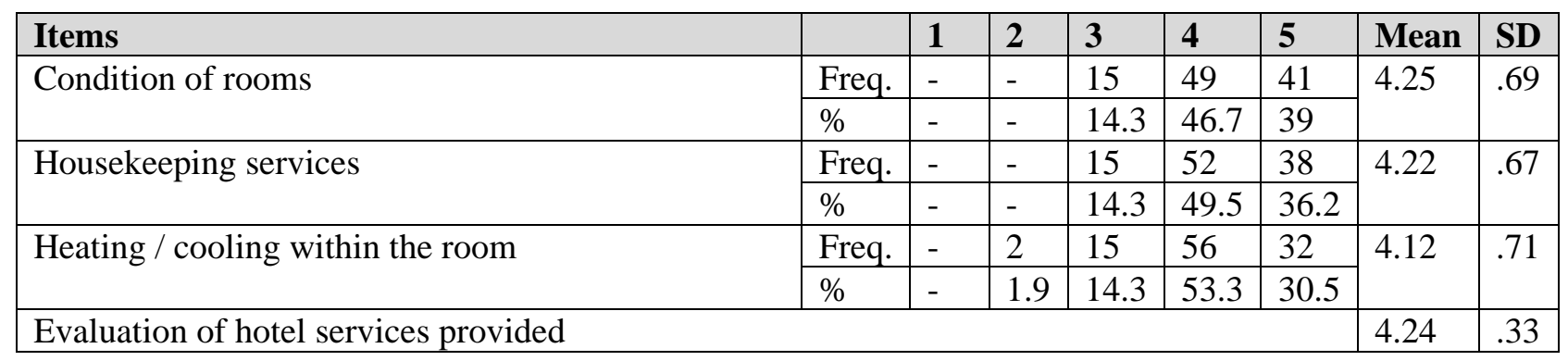

Results in table 10 illustrates that the hotel services provided in Nubian society were characterized by high level of service (mean $=4.24 \& \mathrm{SD}=.33$ ). Moreover, table 10 indicats that quality of food and décor have the highest level of services provided in Nubian society by mean 4.56 for both, followed by quality of beverage and cleanliness by mean 4.33 for both, then the friendliness, courtesy and responsiveness of staff by mean 4.31 , then quality of service by mean 4.26. Besides, condition of rooms by mean 4.25, then public areas and housekeeping services by mean 4.22 for both, followed by value for price paid by mean 4.18 , menu variety by mean 4.15 , then heating / cooling within the room by mean 4.12 , then relaxing atmosphere by mean 4.10 , and finally, promptness of service by mean 3.98 .

\section{Pearson correlation analysis}

The Spearman Correlation was used to examine the relationship between advantages of the Nubian inheritance, data resources on the Nubian society and level of hotel services provided as independent variables and motivations of travelling to the Nubian society as dependent variable.

Table 11: Correlation between independent and dependent variables

\begin{tabular}{|l|l|l|}
\hline \multicolumn{2}{|l|}{} & Motivations of travelling to the Nubian society \\
\hline $\begin{array}{l}\text { Advantages of the Nubian } \\
\text { inheritance }\end{array}$ & Correlation Coefficient & $.420^{* *}$ \\
\cline { 2 - 3 } $\begin{array}{l}\text { Data resources on the } \\
\text { Nubian society }\end{array}$ & Sig. & .000 \\
\cline { 2 - 3 } $\begin{array}{l}\text { Level of hotel services } \\
\text { provided }\end{array}$ & Sig. & $.481^{* *}$ \\
\cline { 2 - 3 } & Correlation Coefficient & .500 \\
\hline
\end{tabular}

As seen in table 11, there is a positive and significant relationship between independent variables and dependent variable. Results showed that the value of correlation between advantages of the Nubian inheritance and motivation of travelling to the Nubian society was $.420 * *$.Additionally, table 11 depicts that the value of correlation between data resources on the Nubian society and motivation of travelling to the Nubian society was .481**, and the value between level of hotel services provided and motivation of travelling to the Nubian society was $.540 * *$. Results revealed that the highest value of correlation was between level of hotel services provided and motivation of travelling to the Nubian society, then between data resources on the Nubian society and motivation of travelling to the Nubian society, and finally, between advantage of the Nubian inheritance and motivation of travelling to the Nubian society

\section{Simple linear regression analyses}

A simple linear regression analysis has been used to test the significance impact of independent variable on dependent variable.

Table 12: Simple Linear Regression analysis

\begin{tabular}{|l|l|l|l|l|}
\hline & $\mathbf{R}^{2}$ & $\mathbf{F}$ & Sig. & Results \\
\hline $\begin{array}{l}\text { Impact of advantages of the Nubian inheritance on motivation of } \\
\text { travelling to the Nubian society }\end{array}$ & .176 & 22.051 & 0.000 & Accepted \\
\hline $\begin{array}{l}\text { Impact of data resources on the Nubian society on motivation of } \\
\text { travelling to the Nubian society }\end{array}$ & .232 & 31.036 & 0.000 & Accepted \\
\hline
\end{tabular}




\begin{tabular}{|l|l|l|l|l|}
\hline $\begin{array}{l}\text { Impact of level of hotel services provided on motivation of travelling } \\
\text { to the Nubian society }\end{array}$ & .291 & 42.355 & 0.000 & Accepted \\
\hline
\end{tabular}

Table 12 depicts the Simple linear Regression analysis between advantages of the Nubian inheritance, data resources on the Nubian society and level of hotel services provided and motivations of travelling to the Nubian society. Results showed that advantages of the Nubian inheritance clearly affect positively and significantly motivation of travelling to the Nubian society by $17.6 \%$ (F Value $=22.051$; Sig=.000), this mean that advantages of the Nubian inheritance enhance motivation of travelling to the Nubian society. Also, table 12 indicats that data resources on the Nubian society affects positively and significantly motivation of travelling to the Nubian society by $23.2 \%$ (F Value $=31.036$; $\mathrm{Sig}=.000$ ). This means that data resources on the Nubian society raise motivation of travelling to the Nubian society. Moreover, level of hotel services provided affects positively and significantly motivation of travelling to the Nubian society by $29.1 \%$ (F Value= 42.355; Sig=.000). This mean that level of hotel services provided enhance motivation of travelling to the Nubian society. Hence, H1, H2, H3 are accepted.

Kruskal-Wallis Test

Table 13: The differences among age with regard to motivation of travelling to the Nubian society according to Kruskal-Wallis test

\begin{tabular}{|l|l|l|l|l|l|l|}
\hline & Age & N & Mean Rank & Chi-Square & df & Sig. \\
\hline \multirow{3}{*}{$\begin{array}{l}\text { Motivation of travelling to the } \\
\text { Nubian society }\end{array}$} & $15-24$ & 30 & 54.83 & 6.680 & 3 & .083 \\
\cline { 2 - 5 } & $25-34$ & 21 & 41.31 & & & \\
\cline { 2 - 4 } & $35-44$ & 25 & 49.68 & & & \\
\cline { 2 - 4 } & More than45 & 29 & 62.43 & & & \\
\hline
\end{tabular}

As showed in table 13, there is no significant differences between age categories and motivation of travelling to the Nubian society where the $\mathrm{p}$ values for all of them were above .05. Therefore, $\mathrm{H} 4$ is rejected.

\section{Results and Recommendations}

On view of aforementioned in the classification of the questionnaire sections, it is obvious that there is a positive and significant relationship between independent variables and dependent variable. Results revealed that the highest value of correlation was between level of hotel services provided and motivation of travelling to the Nubian society, then between data resources on the Nubian society and motivation of travelling to the Nubian society, and finally, between advantage of the Nubian inheritance and motivation of travelling to the Nubian society. In conclusion, the results of the study showed that:

- There is an agreement that there was a high level of motivation of travelling to the Nubian society.

- The hotel services provided in Nubian society were characterized by high level of service, which the statement of the quality of food and décor have the highest level of services provided in Nubian.

- There are no significant differences between age categories and motivation of travelling to the Nubian society.

\section{Recommendations}

- Developing the infrastructure in Nubian society and with all tourist services and facilities.

- Ease of access to the Nubian society, and development of the road network and means of transportation.

- Improving the quality of tourism services in Nubian society. 
- Putting the Nubian tourism product on the Egyptian tourism map and put it within the tourism programs.

- Highlighting Nubian heritage differently, its marketing is dependent on advanced technology.

- The commitment of the Ministry of Tourism and the concerned organizations to provide financial, human and material support for the development of the tourism product in Nubia.

- Raising awareness of Nubian citizens of the importance of tourism and how to deal with tourists.

\section{References}

Ahmed, Z.U. (1991). The influence of the components of a state's tourist image on product positioning strategy, Tourism Management,12(4), 331-340.

Armstrong, G. and Kotler, P. (2005). Marketing: An Introduction. 7th Edition, Prentice Hall, Upper Saddle River, 581.

Chaudhuri, A. (2002). How brand reputation affects the advertising brand equity link. Journal of Advertising Research, 42(3), 33-43.

Bowen, D.E. and Schneider, B. (1988). "Services marketing and management: implications for organizational behavior", in Staw, B.M. and Cummings, L.L. (Eds), Research in Organizational Behavior, An Annual Series of Analytical Essays and Critical Reviews, JAI Press, Greenwich, CT.

British Columbia Ministry of Jobs, Tourism and Skills Training, (2013). Retrieved from https://www.bcbudget.gov.bc.ca/2015/sp/pdf/ministry/jtst.pdf Accessed on 1/2/2020.

Bryman, A. and Bell, E. (2007). Business research methods. Oxford University Press, England.

Buhalis, D., \& Darcy, S. (2011). Accessible tourism: Concepts and issues. London: Channel View Publications.

Chen J.L., Li G. and Song H., (2016). Managing tourist satisfaction: An index approach, In: Uysal M., Schwartz Z. and Sirakaya-Turk E., (Eds.), Management science in hospitality and tourism: Theory, practice, and applications, Apple Academic Press; Palm Bay, FL, 328-342.

Cooper, C., Fletcher, J., Fyall, A, Gilbert, D and Wanhill, S (2008). Tourism: Principles and Practice, Harlow.

Davis, K. (2013). A (kind of) brief history of marketing (inforgraphic). Entrepreneur. Retrieved from www.entrepreneur.com/article/22743. Accessed on 22/1/2020.

Guo, X., Dong, Y., \& Ling, L. (2016). Customer perspective on overbooking: The failure of customers to enjoy their reserved services, accidental or intended? Journal of Air Transport Management, 53(6), 65-72.

Guo, X., Zheng, X., Ling, L., \& Yang, C. (2014). Online coopetition between hotels and online travel agencies: From the perspective of cash back after stay. Tourism Management Perspectives, 12, 104-112.

Hudson, S. (2008). Tourism and hospitality marketing: A global perspective. London: SAGE Publications Ltd.

Hwang, J., \& Wen, L. (2009). The effect of perceived fairness toward hotel overbookingand compensation practices on customer loyalty. International Journal of Contemporary Hospitality Management, 21(6), 659-675.

Jha, S.M., (2010). Hotel marketing. New Delhi: Himalaya Publishing House.

Kotler, P., \& Fox, K. (1995). Strategic Marketing for Educational Institutions. Upper Saddle River, NJ: Prentice-Hall.

Kotler, P., Keller, K. L., Brady, M., Goodman, M., \& Hansen, T. (2009). Marketing management. Harlow, England: Prentice Hall. 
Kwun, D. J. W. (2010). How extended hotel brands affect the lodging portfolio. Journal of Retail \& Leisure Property, 9(3), 179-191.

Laroche, M., Bergeron, J. and Goutaland, C. (2001). A three-dimensional scale of intangibility. Journal of Service Research, 4 (1), 26-38.

Lim, C., \& McAleer, M. (2005). Analysing the behavioral trends in tourist arrivals from Japan to Australia. Journal of Travel Research, 41(3), 265-271.

Lo, W. (2005). Reconciling Efficient Markets with Behavioral Finance: The Adaptive Markets Hypothesis. Journal of Investment Consulting, 7(2), 21-44.

Lovelock, C. and Gummesson, E. (2004). Whither service marketing? In search of a new paradigm and fresh perspective. Journal of Service Research,7(1), 20-41.

McCabe, S. (2009). Marketing Communications in Tourism and Hospitality: Concepts, Strategies and Cases. Hospitality, leisure, and tourism series, Elsevier Press.

McDougall, G.H.G. and Snetsinger, D.W. (1990). The intangibility of services: measurement and competitive perspectives. Journal of Services Marketing, 4(4), 27-40.

McDowall S., (2011). The festival in my hometown: The relationships among performance quality, satisfaction, and behavioral intentions, International Journal of Hospitality \& Tourism Administration, 12(4), 269-288.

Moeller, S. (2010). Characteristics of services - a new approach uncovers their value. Journal of Services Marketing, 24(5), 359-368.

Oliver R.L., A (1980). Cognitive model of the antecedents and consequences of satisfaction decisions. Journal of Marketing Research, 17(4), 460-469.

P. Kotler \& G. Armstrong (2010). Principles of Marketing”, New Jersey: Pearson Prentice Hall.

Parasuraman, A., Zeithaml, V. A., \& Berry, L. L. (1988). SERVQUAL: A multiple-item scale for measuring consumer perceptions of service quality. Journal of Retailing, 64(1), 12-40.

Shaheer, I., Insch, A., \& Carr, N. (2018). Tourism destination boycotts - Are they becoming a standard practise? Tourism Recreation Research, 43(1), 129-132.

Siniscalco, M. T., \& Auriat, N. (2005). Questionnaire design: Quantitative research methods in educational planning. Paris: UNESCO International Institute for Educational Planning.

Song H., van der Veen R., Li G. and Chen J.L., (2012). The Hong Kong tourist satisfaction index, Annals of Tourism Research,39(1), 459-479.

United Nations World Tourism Organization (UNWTO). 2005. Tourism highlights 2005, Madrid: Author.

Vargo, S. and Lusch, R.F. (2004). "The four service marketing myths: remnants of a goodsbased, manufacturing model", Journal of Service Research, 6,324-35.

Weber K., (1997). The assessment of tourist satisfaction using the expectancy disconfirmation theory: A study of the German travel market in Australia, Pacific Tourism Review, 1(1), 3545.

World Travel and Tourism Council (2017). Travel \& Tourism - Economic Impact 2019, (Online) Available at: https://www.google.com/search?sxsrf=ALeKk030UsmEKz2RhxDwfr0EOMuwWlkoQ:1588367249123\&q=pdf+world+travel+and+tourism+council+(2019)+trav el+\%26+tourism+\%E2\%80\%93+economic+impact+2019\&spell=1\&sa=X\&ved=2ahUKEwi vlqCNyZPpAhVXA2MBHU1IB1IQBSgAegQIDBAp\&biw=1366\&bih=657 Accessed on 20/4/2020

Wright, L.K. (1995). Avoiding services marketing myopia, in Glynn, J.W. and Barnes, J.G. (Eds), Understanding Service Management: Integrating Marketing, Organizational Behavior, Operations and Human Resource Management, Wiley, Chichester. 
Xu Z. and Zhang J., (2016). Antecedents and consequences of place attachment: A comparison of Chinese and Western urban tourists in Hangzhou, China, Journal of Destination Marketing \& Management, 5 (2), 86-96.

Zeithaml, V.A., Parasuraman, A. and Berry, L.L. (1985). Problems and strategies in service marketing, Journal of Marketing, 49(2), 33-4.

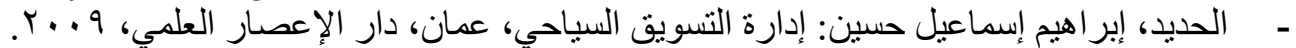

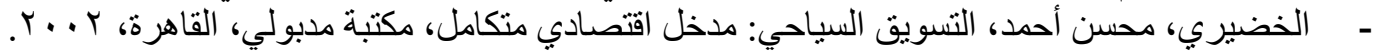

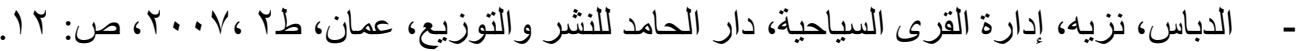

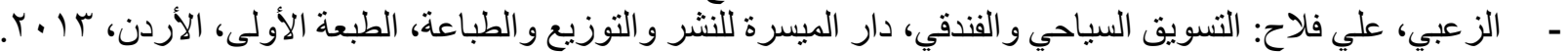
- السر ابي و آخرون، علاء حسين: التسويق و المبيعات السياحية والفندقية، دار الجرير للنشر و التوزيع، عمان الأردن، r. 11

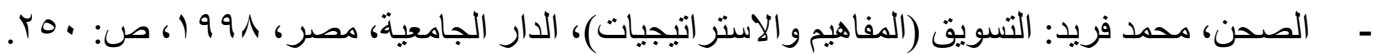

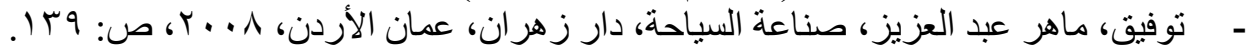

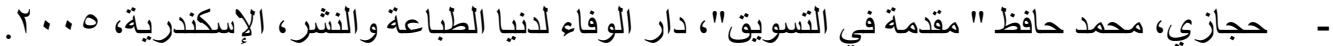

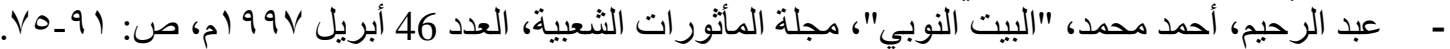

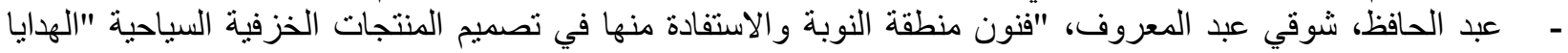

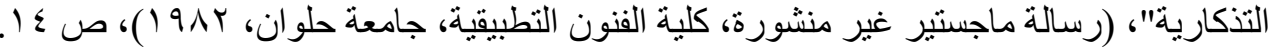

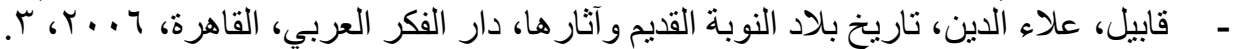

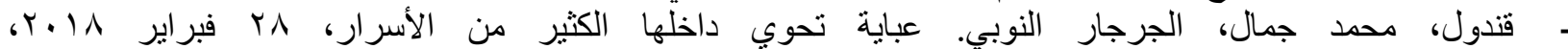
http://www.araged.com

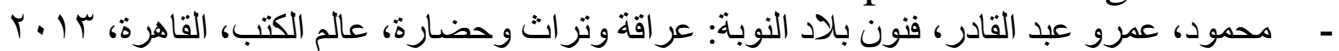

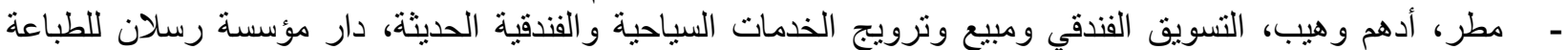

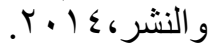

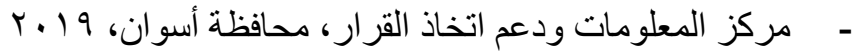

